This is an Accepted Manuscript of an article published by Taylor \& Francis in Environmental Technology on 2019, available online: https://doi.org/10.1080/09593330.2018.1464066

\title{
Comparative removal of emerging contaminants from aqueous solution by adsorption on an activated carbon
}

\author{
A. Gil*, N. Taoufik, A.M. García, S.A. Korili \\ Department of Applied Chemistry, Building Los Acebos, Public University of Navarra, \\ Campus of Arrosadia, E-31006 Pamplona, Spain \\ Institute for Advanced Materials-INAMAT, Public University of Navarra, Campus Arrosadia, \\ 31006 Pamplona, Spain \\ Antonio Gil, E-mail: andoni@unavarra.es; Nawal Taoufik, E-mail: \\ nawal.taoufik@gmail.com; Ana Ma García, E-mail: anamaria00@gmail.com; Sophia A. \\ Korili, E-mail: sofia.korili@unavarra.es
}

\begin{abstract}
Batch sorption experiments were performed to study the adsorption of six emerging pollutants from aqueous solutions using a commercial granular activated carbon as adsorbent. Caffeine, clofibric acid, diclofenac, gallic acid, ibuprofen and salicylic acid were selected as representative contaminants. The activated carbon was characterized by nitrogen adsorption at $77 \mathrm{~K}$, and through the determination of point of zero charge. The effects of several operational parameters, such as $\mathrm{pH}$, initial concentration of organic molecules, mass of adsorbent and contact time, on the sorption behavior were evaluated. The contact time to attain equilibrium for maximum adsorption was found to be $40 \mathrm{~min}$. The kinetic data were correlated to several adsorption models and the adsorption mechanism found to follow pseudo-second-order and intraparticle-diffusion models, with external mass transfer predominating in the first $15 \mathrm{~min}$ of the experiment. The equilibrium adsorption data were
\end{abstract}


analyzed using the Freundlich, Langmuir and Toth isotherm equation models. The similar chemical structure and molecular weight of the organic pollutants studied make the adsorption capacity of the activated carbon used very similar for all the molecules.

Keywords: adsorption, activated carbon, emerging water pollutants, pharmaceutical pollutants.

* Corresponding author: andoni@unavarra.es. Tel.: +34 948169602. 


\section{Introduction}

Although research studies in the pollutants field have tended to focus on the problem of priority pollutants, attention paid to emerging unregulated compounds increases continuously. Future regulation for emerging pollutants depends on the results obtained from the research on their potential health effects and from the monitoring of data regarding their occurrence [1]. Examples of this kind of compounds are pharmaceuticals, steroids and hormones, surfactants, flame retardants, industrial additives and agents, and gasoline additives [1]. Many undesired effects of these contaminants and their degradation products have been summarized in the literature [2]. Some of these contaminants do not even need to be persistent in the environment to cause negative effects, since their high transformation rate is compensated by their continuous introduction into the aquatic medium [3].

Several recent studies on the removal of emerging pollutants from water have revealed that coagulation-flocculation processes are generally not suitable $[4,5]$. Conventional biological treatment of these pollutants in wastewater treatment plants is time-consuming and not always effective, since not the whole range of the emerging pollutants can be removed this way [6]. Alternative technologies, such as adsorption on porous materials, use of membrane reactors, advanced oxidation processes and catalytic wet oxidation, have been found to be effective in removing several organic compounds from water [2].

Adsorption is an attractive method for the removal of contaminants from effluents since, if the adsorption system is designed correctly, it will provide a high-quality treated effluent which can be suitable for reuse. In comparison with other processes for the treatment of polluted aqueous effluents, the adsorption process allows flexibility in terms of both design and operation. Additionally, as the adsorption is sometimes reversible, the sorbent can be regenerated, thereby resulting in significant cost savings. Regarding the choice of the adsorbent, activated carbons are usually the first option in water treatment applications where 
competitive adsorption is not important. Alternative adsorbents can be zeolites [7-9], metal organic frameworks [10-12] and clays [9,13-18], amongst others.

The adsorption of emerging pollutants on activated carbons has been studied by several authors over the past decade [19-27]. Thus, removal of clofibric acid from aqueous solution using cork-based activated carbons was studied by Mestre et al. [20]. These authors noted the importance of $\mathrm{pH}$ for clofibric acid adsorption and explained their findings on the basis of the solvation energies of undissociated and dissociated clofibric acid species rather than the chemical properties of the adsorbent. Similarly, the adsorption of caffeine, diclofenac, ibuprofen, carbamazepine and tetracycline on various activated carbons was investigated by Álvarez-Torrellas et al. [24,27], who linked their experimental adsorption results to the textural and chemical surface properties of the adsorbents. Rakic et al. [26] evaluated the ability of three commercial activated carbons to adsorb salicylic acid, acetylsalicylic acid, atenolol and diclofenac. The maximal adsorption capacities were correlated to the textural properties of the activated carbons while the acid/base features of the adsorbents and the molecular structures of the adsorbate molecules also played a role. Other carbon based materials as carbon nanotubes, chitosan, biochars, graphene, polymers, among others, have also been evaluated as adsorbents for the removal of organic contaminants [28-32].

In light of the above, the present study was motivated to test the effectiveness of a commercial granular activated carbon for the removal by adsorption of emerging contaminants at a concentration of up to $15 \mathrm{mg} / \mathrm{dm}^{3}$ in water, the maximum solubility limit of all organic molecules. Caffeine (CF), clofibric acid (CA), diclofenac (DF), gallic acid (GA), ibuprofen (IB) and salicylic acid (SA) were considered the representative contaminants. An additional objective of the work was to test various kinetic and equilibrium models for the adsorption of these emerging contaminants on the granular activated carbon in singlecomponent systems. 


\section{Experimental procedure}

\subsection{Materials}

The adsorbent used in this work was a granular acid-washed activated carbon, Hydrodalco 3000, kindly supplied by Cabot Corporation. This carbon is produced by steam activation of coal and is used in water purification because of its excellent adsorption capacity for organics.

The chemical reagents were purchased from Sigma-Aldrich and were all of high purity $(>98-99 \%)$. The chemical structures of all organic molecules used as adsorbates are shown in Table 1. The main physicochemical characteristics of the adsorbates, obtained from the ChemIDplus advanced database, are also included in Table 1. The aqueous solutions used in adsorprtion experiments were prepared using ultrapure water obtained with a Milli-Q apparatus (Millipore).

\subsection{Characterization techniques}

The point of zero charge was determined using the salt addition method [33]. The initial $\mathrm{pH}$ values $\left(\mathrm{pH}_{\mathrm{i}}\right)$ of aqueous solutions of $\mathrm{NaCl} 0.01 \mathrm{~mol} / \mathrm{dm}^{3}$ were adjusted to a $\mathrm{pH}$ range of $2-$ 12 using either $0.1 \mathrm{~mol} / \mathrm{dm}^{3} \mathrm{HCl}$ or $0.1 \mathrm{~mol} / \mathrm{dm}^{3} \mathrm{NaOH}$; then, $0.15 \mathrm{~g}$ of adsorbent was added to $50 \mathrm{~cm}^{3}$ of solution. The suspensions were sealed and shaken for $48 \mathrm{~h}$ at ambient temperature; finally they were filtered and the $\mathrm{pH}\left(\mathrm{pH}_{\mathrm{f}}\right)$ of the supernatant was measured. The shift in $\mathrm{pH}, \Delta \mathrm{pH}=\mathrm{pH}_{\mathrm{i}}-\mathrm{pH}_{\mathrm{f}}$, was plotted against $\mathrm{pH}_{\mathrm{i}}$ and the point of zero charge was determined as the intersection of the curve with the $\mathrm{pH}$ axis.

Nitrogen ( $>99.999 \%)$ adsorption measurements at $77 \mathrm{~K}$ were performed on a Micromeritics ASAP 2010 volumetric adsorption analyzer. In each run, about $0.1 \mathrm{~g}$ of activated carbon was used, after outgassing at $473 \mathrm{~K}$ for $16 \mathrm{~h}$ to remove any adsorbed 
molecules. The adsorption-desorption isotherms were obtained over the relative pressure range from 0 to 1 to determine the surface area and the pore volume.

\subsection{Adsorption procedure}

The adsorption experiments were performed in batch mode. In kinetic tests, and considering previous works of our research group [34], $50 \mathrm{mg}$ of adsorbent was added to glass tubes containing $10 \mathrm{~cm}^{3}$ aqueous solutions of the pollutants at initial concentrations of 5 , 10 and $15 \mathrm{mg} / \mathrm{dm}^{3}$. The effect of the adsorbent dose was studied by varying the amount of the absorbent $(25,50$ and $100 \mathrm{mg})$ which was added to the solutions with an initial pollutant concentration of $15 \mathrm{mg} / \mathrm{cm}^{3}$. The effect of the $\mathrm{pH}$ on the adsorption was studied for the solutions that contained $15 \mathrm{mg} / \mathrm{dm}^{3}$ pollutant and $50 \mathrm{mg}$ adsorbent, for which the initial $\mathrm{pH}$ values were adjusted to 2.8 or 6.0 by proper addition of $\mathrm{HCl}$ or $\mathrm{NaOH}$. After been agitated for a predetermined time in an orbital shaker at room temperature, the suspensions were filtered through $0.45 \mu \mathrm{m}$ Durapore membrane filters. The concentration of the pollutant remaining in aqueous solution was measured using a Jasco V-730 UV-Vis spectrometer at the maximum absorption wavelength which was determined experimentally for each molecule (Table 1).

Various contaminant solutions with several concentrations were prepared to determine the equilibrium adsorption capacity of the activated carbon. In equilibrium tests, $50 \mathrm{mg}$ of adsorbent was added to glass tubes containing $10 \mathrm{~cm}^{3}$ of the contaminant solution at a concentration ranging from 0 to $500 \mathrm{mg} / \mathrm{dm}^{3}$. The $\mathrm{pH}$ was adjusted to 6.0 and the suspensions were agitated in the shaker for $2 \mathrm{~h}$. The rest of the procedure was similar to the one previously described for kinetic tests. The amount of organic pollutant adsorbed by the solid at equilibrium was calculated according to the Equation 1 , where $C_{e}\left(\mathrm{mg} / \mathrm{dm}^{3}\right)$ is the pollutant concentration at equilibrium. All adsorption experiments were performed at least twice and the results are reported as an average. 


\subsubsection{Theoretical approach: Adsorption kinetics}

Two types of kinetic modeling approaches have been considered in the adsorption literature to describe the transport of adsorbates inside adsorbent particles [35]. The first type considers simple relationships between the adsorption performance and operating conditions. These models show how the mean adsorbent loading $\left(q_{t}\right)$ changes with adsorption time. Models in this category include pseudo-first- and pseudo-second-order rate equations. The parameters obtained from these models are used for adsorbent screening procedures. The second approach is the use of phenomenological models that attempt to describe the physics of the process. Information about the mechanism of adsorption can be obtained from the second type of models using the kinetic experimental results and the equilibrium adsorption data.

In order to investigate the adsorption process for the organic molecules in this study, pseudo-first- and pseudo-second-order rate equations and the intra-particle diffusion model were used and applied to test the experimental data. The first-order rate equation, or the socalled Lagergren equation, can describe the initial phase in the adsorption process, although as adsorption progresses the adsorption data may deviate from the fitted curve. The secondorder rate equation suggests that chemisorption is the rate-controlling mechanism. Moreover, it has frequently been employed to analyze adsorption data obtained from various experiments with several types of adsorbates and adsorbents, as reviewed by Liu and Shen [36].

The mass balance for the adsorbate in a batch liquid-phase system before attainment of adsorption equilibrium, assuming first- or second-order kinetics for the driving force term, is represented by Equations (1) and (2), respectively:

$$
-\frac{d n}{d t}=-V \frac{d C}{d t}=k_{1} \cdot V \cdot\left(C-C_{e}\right)
$$




$$
-\frac{d n}{d t}=-V \frac{d C}{d t}=k_{2} \cdot \frac{V^{2}}{m} \cdot\left(C-C_{e}\right)^{2}
$$

where $n(\mathrm{mg})$ is the adsorbate mass in the liquid phase, $V\left(\mathrm{dm}^{3}\right)$ is the volume of solution, $C\left(\mathrm{mg} / \mathrm{dm}^{3}\right)$ is the solute concentration, $m(\mathrm{~g})$ is the adsorbent mass, $t(\mathrm{~min})$ is the time of contact and $k_{1}(1 / \mathrm{min})$ and $k_{2}(\mathrm{~g} / \mathrm{mg} \cdot \mathrm{min})$ are the adsorption kinetic constants for pseudo-first and pseudo-second order kinetics, respectively.

Integrating the Equations (1) and (2) between $t=0$ and time $t$, and considering the initial conditions (for $t=0, C=C_{0}$ ), the following equations are obtained:

$$
\begin{aligned}
& \ln \left(\frac{C_{t}-C_{e}}{C_{0}-C_{e}}\right)=-k_{1} \cdot t \\
& C_{t}=C_{e}+\frac{V \cdot m \cdot\left(C_{0}-C_{e}\right)}{m+k_{2} \cdot V \cdot\left(C_{0}-C_{e}\right) \cdot t}
\end{aligned}
$$

The relationship between the concentration $(C)$ of the organic molecule in the aqueous solution and the amount $(q)$ adsorbed on the solid, based on the concept that the organic molecule mass that is removed from the liquid phase is transferred to the solid, is given by the following equation:

$$
q_{t}=\frac{V \cdot\left(C_{0}-C_{t}\right)}{m}
$$

where $q$ is expressed in $\mathrm{mg}$ of adsorbate per $\mathrm{g}$ of adsorbent.

Taking into account Equation (5), Equations (3) and (4) become: 


$$
\begin{aligned}
& q_{t}=q_{e} \cdot\left(1-\exp \left(-k_{1} \cdot t\right)\right) \\
& q_{t}=\frac{k_{2} \cdot q_{e}^{2} \cdot t}{1+k_{2} \cdot q_{e} \cdot t}
\end{aligned}
$$

Equations (6) and (7) are widely used to interprete the experimental results obtained for aqueous pollutants $[10,13,27,37-39]$. The parameters in these equations are estimated by fitting the models to the experimental data by non-linear regression analysis.

Intraparticle diffusion is the rate-controlling step in the case of well-mixed solutions, for which the intraparticle diffusivity is constant and the uptake of adsorbate by the adsorbent is low compared to the total quantity of adsorbate present in the solution. The equation for the intraparticle diffusion model is represented by the Morris and Weber approach:

$$
q_{t}=k_{3} \cdot t^{0.5}
$$

where $k_{3}\left(\mathrm{mg} / \mathrm{g} \cdot \mathrm{min}^{0.5}\right)$ is the intraparticle diffusion rate constant. This model has been applied for several adsorption systems [13,27,40-42].

Following with the physics description of the adsorption process, the external mass transfer or boundary layer effects can be analyze from a model which assumes that the surface concentration of the adsorbate is negligible at time $t=0$. If the system is well-stirred, the concentrations of adsorbate on the adsorbent surface and in the liquid phase must be uniform. The external mass-transfer coefficient can be obtained from the Furusawa and Smith model [43]:

$$
\frac{C_{t}}{C_{0}}=\frac{1}{1+m_{S} \cdot k_{T}}+\frac{m_{S} \cdot k_{T}}{1+m_{S} \cdot k_{T}} \exp \left(-\frac{1+m_{S} \cdot k_{T}}{m_{S} \cdot k_{T}} \cdot k_{F S} \cdot \frac{m}{V} S_{e x t} \cdot t\right)
$$


where $k_{T}\left(\mathrm{dm}^{3} / \mathrm{g}\right)$ is the equilibrium constant in the Toth isotherm (see Equation 13), $m_{S}$ $\left(\mathrm{g} / \mathrm{dm}^{3}\right)$ is the concentration of adsorbent, $S_{\text {ext }}\left(\mathrm{m}^{2} / \mathrm{g}\right)$ is the external specific surface area and $k_{F S}(\mathrm{~cm} / \mathrm{s})$ is the external mass-transfer coefficient.

The effective diffusion coefficient for the adsorption process in porous adsorbents can be determined from the fractional approach to the equilibrium, $F(t)$ [44]:

$$
\frac{C_{0}-C_{t}}{C_{0}-C_{e}}=F(t)=\left[1-\exp \left(-\frac{\pi^{2} \cdot D \cdot t}{r^{2}}\right)\right]^{0.5}
$$

where $D\left(\mathrm{~m}^{2} / \mathrm{s}\right)$ is the intraparticle-diffusion coefficient and $r(\mathrm{~m})$ is the particle size radius assuming a spherical geometry.

\subsubsection{Theoretical approach: Adsorption models}

The Freundlich isotherm model is an empirical equation employed to describe the adsorption processes in heterogeneous adsorbents, especially for organic compounds and highly interactive species on activated carbon [45]. The Freundlich isotherm equation can be expressed as follows:

$$
q_{e}=k_{F} \cdot C_{e}^{1 / m_{F}}
$$

where $k_{F}$ and $m_{F}$ are empirical constants that indicate adsorption magnitude and effectiveness.

The well-known Langmuir model was developed for monolayer coverage of homogeneous adsorbent surfaces [45]: 


$$
q_{e}=\frac{k_{L} \cdot q_{L} \cdot C_{e}}{1+k_{L} \cdot C_{e}}
$$

where $k_{L}\left(\mathrm{dm}^{3} / \mathrm{mg}\right)$ and $q_{L}(\mathrm{mg} / \mathrm{g})$ are the equilibrium adsorption constant related to the affinity of binding sites, and the monolayer adsorption capacity, respectively.

Finally, the Toth model is an improvement of the Freundlich and Langmuir equations. The equation describes the adsorption behavior of various adsorbates under sub-critical conditions.

$$
q_{e}=\frac{k_{T} \cdot q_{T} \cdot C_{e}}{\left[1+\left(k_{T} \cdot C_{e}\right)^{m_{T}}\right]^{1 / m_{T}}}
$$

where $q_{T}(\mathrm{mg} / \mathrm{g}), k_{T}\left(\mathrm{dm}^{3} / \mathrm{mg}\right)$ and $m_{T}$ are the Toth constants.

\section{Results and discussion}

\subsection{Characterization of the adsorbent}

The nitrogen adsorption isotherm for the activated carbon studied herein was of type II in the Brunauer, Deming, Deming and Teller (BDDT) classification [46], and the hysteresis loop was of type IIIb in the Rouquerol et al. classification [47]. The BET specific surface area was found to be $578 \mathrm{~m}^{2} / \mathrm{g}$ and the total pore volume obtained at a relative pressure of 0.98 was $0.564 \mathrm{~cm}^{3} / \mathrm{g}$. The external specific surface area and micropore volume, estimated using the $t$-plot method [46], were $159 \mathrm{~m}^{2} / \mathrm{g}$ and $0.206 \mathrm{~cm}^{3} / \mathrm{g}$, respectively. These results indicate that the activated carbon used as adsorbent is a mesoporous material.

\subsection{Adsorption experiments}


Several factors, such as the solution $\mathrm{pH}$, the adsorbent dose and the initial concentration of the adsorbate, amongst others, can play important roles in the adsorption process. The $\mathrm{pH}$ can simultaneously affect the surface charge of the adsorbent, the degree of ionization of functional groups of the adsorbate, and the adsorption mechanism [20]. Thus, the effect of $\mathrm{pH}$ on the removal of organic molecules by the activated carbon was studied to gain further insight into the adsorption process. To that end, the effect of $\mathrm{pH}$ on the adsorption was determined at values of 2.8 and 6 , with a CA, GA and SA feed concentration of $15 \mathrm{mg} / \mathrm{dm}^{3}$ and an adsorbent dose of $50 \mathrm{mg}$. The results obtained are shown in Figure 1. It can be observed that the percentage organic molecule uptake increases with contact time until an almost constant value is reached. At this point the amount of adsorbate being removed from aqueous solution by the activated carbon is in a state of dynamic equilibrium with the amount of organic molecule desorbed from the activated carbon. It can also be seen that CA is adsorbed to a greater extent, followed by GA and SA. Considering both pHs, no appreciable differences were observed for the amount of salicylic acid retained on the surface of the activated carbon. For the other two molecules, the amount adsorbed increases by between $19 \%$ and $23 \%$ when the $\mathrm{pH}$ is below $\mathrm{pH}_{\mathrm{pzc}}$.

The adsorbent dose is an important parameter that strongly influences the adsorption process by affecting the adsorption capacity of the adsorbent. Various doses of between 25 and $100 \mathrm{mg}$ activated carbon were investigated in this study, and the results are summarized in Figures 2 and 3. It can be seen that the equilibrium adsorption capacity decreased with increasing amount of adsorbent dose. This phenomenon may be explained as a result of particle interactions such as partial overlapping or aggregation of adsorption sites, thus causing a decrease in the effective adsorbent surface area available to organic molecules and an increase in the diffusion path length. 
The initial organic molecule concentration and contact time is another controlling parameter that strongly influences the adsorption process. As such, a plot of equilibrium adsorption capacity versus contact time for various initial organic molecule concentrations of between 5 and $15 \mathrm{mg} / \mathrm{dm}^{3}$ is also shown in Figures 2 and 3. Experiments were performed with a fixed adsorbent dose of $50 \mathrm{mg}$, at a fixed temperature at $\mathrm{pH} 6$, and shaken until equilibrium was achieved. The adsorption capacity for the activated carbon increased from 0.60 to 3.07 $\mathrm{mg} / \mathrm{g}$ in the case of CA, GA and SA, and from 0.18 to $3.14 \mathrm{mg} / \mathrm{g}$ in the case of CF, DF and $\mathrm{IB}$, as the initial concentration of the organic molecule increased from 5 to $15 \mathrm{mg} / \mathrm{dm}^{3}$. This trend can be explained from the perspective of a concentration gradient, which acts as the driving force to overcome the mass transfer resistance of the organic molecule between the aqueous and solid phases. Under our experimental conditions, a higher initial concentration provides a higher driving force for mass transfer of organic molecules, thus leading to a higher adsorption capacity until saturation. The adsorption of organic molecules showed a two-stage behavior: a very rapid initial adsorption over a few minutes (up to $40 \mathrm{~min}$ ), followed by a longer period of much slower uptake. During the initial stage, a large number of active sites on the adsorbent and the interaction between the surface of the adsorbent and the organic molecule enhanced the adsorption. The subsequent lower adsorption may be due to repulsive forces between the organic molecules adsorbed on the adsorbent and those in the bulk phase. More information about this process can be obtained when considering the diffusion mechanism (see the next section). Representative plots of adsorption capacity versus contact time are provided in Figure 4.

\subsection{Kinetic models}

The results relating to kinetic behavior (see Figures 2 and 3, and Tables 2 and 3) reveal that the adsorption of organic molecules can best be described as a pseudo-second-order 
linear reaction. An analysis of the $k_{2}$ values (see Table 3 ) shows the $k_{2}$ values for the acids are greater than those for pharmaceutical molecules (CF, DF and IB). Thus, the adsorption rate of acids on the activated carbon is faster than that for the pharmaceutical molecules. The results also show that the adsorption rate constant decreases as the initial organic molecule concentration increases from 5 to $15 \mathrm{mg} / \mathrm{dm}^{3}$ and as the adsorbent mass increases from 25 to $100 \mathrm{mg}$. An increase in adsorbent mass increases the adsorption rate constant as a result of the higher number of active sites available for adsorption. This process was described by Chu [48], who indicated that, at low initial adsorbate concentration, the adsorbate will bind preferentially to high energy sites. The sites of higher energy are usually taken up by adsorbate molecules first, with sites of lower energy progressively filled as adsorbate loading is increased. It therefore follows that the adsorbate bond in low adsorbate loading situations will result in faster reaction kinetics. Adsorption on lower energy sites, as in the case of high loading, will subsequently result in a decrease in the $k_{2}$ value.

Mass-transfer processes in porous solids are always complicated because of molecular sieve and diffusional effects. Diffusion takes place when the dimensions of the adsorbate molecules are smaller than the pore diameter. However, internal diffusion can be neglected for nonporous, macroporous and mesoporous solids, thus meaning that control is determined by external diffusion processes. For brevity reasons the external mass-transfer coefficients were determined using the Furusawa-Smith method for CF, DF and IB only, and the results are shown in Figure 5 and Table 5. An increase in the initial organic molecule concentration decreases the initial rate of adsorption, as also reported by McKay et al. [49]. This behavior can be attributed to interactions between solute molecules in solution and to increased competition for available adsorption sites. An increase in adsorbent mass decreases the resistance to external mass-transfer and increases the external mass-transfer coefficient. 
Plots of the Morris-Weber relationship for sorption of the organic molecules by the activated carbon, at an initial concentration of $10 \mathrm{mg} / \mathrm{dm}^{3}$, are shown in Figure 6. In light of this figure, it can be seen that the intra-particle diffusion of organic molecules within the activated carbon occurs in two stages [40]. The first linear portion includes the adsorption period from 0 to 16 min and represents the external mass transfer or boundary layer diffusion and the rapid distribution of molecules onto the outer surface of the activated carbon. The second linear portion corresponds to the adsorption period from 25 to $90 \mathrm{~min}$, which represents the intra-particle diffusion and binding of molecules into the internal active sites of the activated carbon. The slope of the linear portion (see Table 4) indicates the rate of the adsorption process, which decreases with contact time. As the organic molecule diffuses into the inner structure of the activated carbon, the porosity available for diffusion decreases. The calculated effective diffusion coefficients are summarized in Table 6. The relatively low value of $D\left(10^{-5} \mathrm{~L} / \mathrm{s}\right)$ also indicates the low role of intraparticle diffusion in the adsorption of organic molecules on the mesoporous activated carbon. It is clear from the data that, as the mass of adsorbent increases from 25 to $100 \mathrm{mg}$, the effective diffusion coefficients also increase. Various explanations for this have been proposed by several authors when studying dye adsorption [50-52].

\subsection{Adsorption isotherms}

The most common representation of adsorbate concentration and quantity of material adsorbed is the adsorption isotherm. The equilibrium adsorption isotherm is fundamental for describing the interactive behavior between solutes and adsorbents, and is the basic requirement in the design of adsorption systems [53]. In this study, the Freundlich, Langmuir and Toth isotherm equations were used to model the experimental data for SA, CF, DF and IB. Adsorption isotherms for the retention of these organic molecules by the activated carbon 
are presented in Figure 7. These isotherms show a characteristic L-type behavior according to the Giles classification, thereby representing a system in which the adsorbate is strongly attracted by the adsorbent [54]. The calculated constants for the isotherm equations, as estimated by non-linear regression, are presented in Table 5. Although all models describe the experimental results well, taking into consideration the parameters obtained, the Toth equation gives better agreement between the theoretical and experimental data than the others. This finding is consistent with other studies which demonstrate that the Toth model correctly describes the adsorption of organic molecules on activated carbons [39].

\subsection{Mechanism of emerging contaminants adsorption on the activated carbon}

It has been reported several possible interactions that can explain the adsorption of organic contaminants on adsorbents: hydrophobic interactions, $\pi-\pi$ stacking interactions, van der Waals forces, electrostatic interactions and hydrogen bonding interactions that can act individually or simultaneously $[28,29]$

The results of adsorption suggest that the commercial adsorbent show very strong adsorption affinity for the organic compounds considered in this study. The attractive or repulsive interactions between the adsorbent surface and the adsorbate are affected by the chemical characteristics of the adsorbents. The point of zero charge $\left(\mathrm{pH}_{\mathrm{pzc}}\right)$ is an important chemical characteristic of adsorbents as it determines the net charge of the adsorbent surface in the solution. Adsorbents have a net negative charge on their surface when the equilibrium $\mathrm{pH}$ of the solution is higher than their $\mathrm{pH}_{\mathrm{pzc}}$, whereas they have a net positive charge when the equilibrium $\mathrm{pH}$ in solution is lower than their $\mathrm{pH}_{\mathrm{pzc}}$. The $\mathrm{pH}_{\mathrm{pzc}}$ value determined for the activated carbon was 4.5. Therefore, the adsorbent has negative charge as the equilibrium $\mathrm{pH}$ of 6 is higher than the $\mathrm{pH}_{\mathrm{pzc}}$ value, thus meaning that electrostatic attractions between the negatively charged surface and the positively charged organic molecules could favor 
adsorption. However, the experimental results also show that there is an interaction between the surface of the activated carbon and the adsorbates at $\mathrm{pH} 2.8$, thus suggesting that the effect of van der Waals and $\pi-\pi$ interactions cannot be neglected. This type of interactions mainly occurred between the $\pi$-electron-depleted aromatic rings (also regions) and the $\pi$-electron-rich regions (or aromatic rings) of the adsorbate and the adsorbent. The role donor/acceptor is not fixed [55].

The molecular size and shape of organic contaminants have also been reported that determine the availability of the adsorption sites on adsorbents. In general, larger molecules have higher adsorption energies, and thus larger differences in molecular size result in better separation in a system with mixed chemicals $[56,57]$. The rate of organic chemical diffusion is also dependent on molecular size and shape. The organic molecules used in this work all have a fairly similar chemical structure between them, as well as a similar molecular weight. Therefore, the behavior in the adsorption by the activated carbon will also be very similar

\section{Conclusions}

In the present study the ability of a commercial granular activated carbon to remove six emerging pollutants from aqueous solutions was evaluated and compared. The results obtained show that the adsorbent shows a similar adsorption capacity for all adsorbates. These results can be explained considering the limited surface chemistry of this type of material.

The kinetic study revealed that stirring for $40 \mathrm{~min}$ is sufficient for the organic molecule/activated carbon system to reach equilibrium. The experimental kinetic data were fitted to pseudo-first- and pseudo-second-order rate equations and the intra-particle diffusion model. The experimental results can best be described as a pseudo-second-order linear reaction. The low value of the calculated effective diffusion coefficients indicates the limited 
role of intraparticle diffusion in the adsorption of the emerging contaminants on the mesoporous activated carbon.

\section{Acknowledgements}

This work was supported by the Spanish Ministry of Science and Innovation (MICINN) through project MAT2013-47811-C2-1-R. N. Taoufik and A.M. García acknowledge financial support from the Spanish Agency for International Development and CooperationAECID through research fellowships. AG also thanks Santander Bank for funding through the Research Intensification Program. 


\section{References}

[1] European Union Directive 2000/60/EC of the European Parliament and of the Council of October 23 2000. Establishing a framework for Community action in the field of water policy.

[2] Bolong N, Ismail AF, Salim MR, et al. A review of the effects of emerging contaminants in wastewater and options for their removal. Desalination 2009;239:229-246.

[3] Fent K, Weston AA, Caminada D. Ecotoxicology of human pharmaceuticals. Aquat Toxicol. 2006;76:122-159.

[4] Adams C, Wang Y, Loftin K, et al. Removal of antibiotics from surface and distilled water in conventional water treatment processes. J Environ Eng. 2002;128:253-260.

[5] Huerta-Fontela M, Galceran MT, Ventura F. Occurrence and removal of pharmaceuticals and hormones through drinking water treatment. Water Res. 2011;45:1432-1442.

[6] Omil F, Suárez S, Carballa M. Criteria for designing sewage treatment plants for enhanced removal of organic micropollutants. In: Fatta-Kassinos D, Bester K, Kümmerer K, editors. Xenobiotics in the urban water cycle, mass flows, environmental process, mitigation and treatment strategies. New York: Springer; 2010. p. 283-306.

[7] Koubaissy B, Joly G, Batonneau-Gener I, et al. Adsorptive removal of aromatic compounds present in wastewater by using dealuminated faujasite zeolite. Ind Eng Chem Res. 2011;50:5705-5713.

[8] Martucci A, Pasti L, Marchetti N, et al. Adsorption of pharmaceuticals from aqueous solutions on synthetic zeolites. Micropor Mesopor Mater. 2012;148:174-183.

[9] Rakic V, Rajic N, Dakovic A, et al. The adsorption of salicylic acid, acetyl-salicylic acid and atenolol from aqueous solutions onto natural zeolites and clays: clinoptilolite, bentonite and kaolin. Micropor Mesopor Mater. 2013;166:185-194. 
[10] Hasan Z, Jeon J, Jhung SH. Adsorptive removal of naproxen and clofibric acid from water using metal-organic frameworks. J Hazard Mater. 2012;209-210:151-157.

[11] Zhou M, Wu Y, Qiao J, et al. The removal of bisphenol-A from aqueous solutions by MIL-53(Al) and mesostructured MIL-53(Al). J Colloid Interface Sci. 2013;405:157-163.

[12] Hasan Z, Khan NA, Jhung SH. Adsorptive removal of diclofenac sodium from water with Zr-based metal-organic frameworks. Chem Eng J. 2016;284:1406-1413.

[13] Gil A, Assis FCC, Albeniz S, et al. Removal of dyes from wastewaters by adsorption on pillared clays. Chem Eng J. 2011;168:1032-1040.

[14] Roca Jalil ME, Vieira R, Azevedo D, et al. Improvement in the adsorption of thiabendazole by using aluminum pillared clays. Appl Clay Sci. 2013;71:55-63.

[15] Gil A, Elmchaouri A, El Mouzdahir Y, et al. Removal of tetrachloroethylene from aqueous solutions by adsorption on clay minerals. Adsorption Science \& Technology $2015 ; 33: 355-367$.

[16] Cabrera-Lafaurie WA, Román FR, Hernández-Maldonado AJ. Single and multicomponent adsorption of salicylic acid, clofibric acid, carbamazepine and caffeine from water onto transition metal modified and partially calcined inorganic-organic pillared clay fixed beds. J Hazard Mater. 2015;282:174-182.

[17] Hamidouche S, Bouras O, Zermane F, et al. Simultaneous sorption of 4-nitrophenol and 2-nitrophenol on a hybrid geocomposite based on surfactant-modified pillared-clay and activated carbon. Chem Eng J. 2015;279:964-972.

[18] Marçal L, de Faria EH, Nassar EJ, et al. Organically modified saponites: SAXS study of its swelling and application to removal of caffeine. ACS Appl Mater Interfaces 2015;7:10853-10862. 
[19] Yu Z, Peldszusand S, Huck PM. Adsorption characteristics of selected pharmaceuticals and an endocrine disrupting compound-Naproxen, carbamazepine and nonylphenol-on activated carbon. Water Res. 2008;42:2873-2882.

[20] Mestre AS, Pinto ML, Pires J, et al. Effect of solution $\mathrm{pH}$ on the removal of clofibric acid by cork-based activated carbons. Carbon 2010;48:972-980.

[21] Ruiz B, Cabrita I, Mestre AS, et al. Surface heterogeneity effects of activated carbons on the kinetics paracetamol removal from aqueous solution. Appl Surf Sci. 2010;256:51715175.

[22] Sotelo JL, Ovejero G, Rodríguez A, et al. Competitive adsorption studies of caffeine and diclofenac aqueous solutions by activated carbon. Chem Eng J. 2014;240:443-453.

[23] Katsigiannis A, Noutsopoulos C, Mantziaras J, et al. Removal of emerging pollutants through Granular Activated Carbon. Chem Eng J. 2015;280:48-57.

[24] Álvarez Torrellas S, García Lovera R, Escalona N, et al. Chemical-activated carbons from peach stones for the adsorption of emerging contaminants in aqueous solutions. Chem Eng J. 2015;279:788-798.

[25] García-Mateos FJ, Ruiz-Rosas R, Marqués MD, et al. Removal of paracetamol on biomass-derived activated carbon: modeling the fixed bed breakthrough curves using batch adsorption experiments. Chem Eng J. 2015;279:18-30.

[26] Rakic V, Rac V, Krmar M, et al. The adsorption of pharmaceutically active compounds from aqueous solutions onto activated carbons. J Hazard Mater. 2015;282:141-149.

[27] Álvarez-Torrellas S, Rodríguez A, Ovejero G, et al. Comparative adsorption performance of ibuprofen and tetracycline from aqueous solution by carbonaceous materials. Chem Eng J. 2016;283:936-947.

[28] $\mathrm{Yu} \mathrm{J-G}$, Zhao X-H, Yang $\mathrm{H}$, et al. Aqueous adsorption and removal of organic contaminants by carbon nanotubes. Sci Total Environ. 2014;482-483:241-251. 
[29] Ersan G, Apul OG, Perreault F, et al. Adsorption of organic contaminants by graphene nanosheets: A review. Water Res. 2017;126:385-398.

[30] Carmalin AS, Lima EC. Removal of emerging contaminants from the environment by adsorption. Ecotox Environ Safety 2018;150:1-17.

[31] de Andrade JR, Oliveira MF, da Silva MGC, et al. Adsorption of pharmateuticals from wáter and wastewater using nonconventional low-cost materials: a review. Ind Eng Chem Res. 2018;57:3103-3127.

[32] Gil A, Santamaría L, Korili SA. Removal of caffeine and diclofenac from aqueous solution by adsorption on multiwalled carbon nanotubes. Colloid Interface Sci Comm. $2018 ; 22: 25-28$.

[33] Benhouria A, Azharul Islam Md, Zaghouane-Boudiaf $\mathrm{H}$, et al. Calcium alginatebentonite-activated carbon composite beads as highly effective adsorbent for methylene blue. Chem Eng J. 2015;270:621-630.

[34] Gil A, Assis FCC, Albeniz S, et al. Removal of dyes from wastewaters by adsorption on pillared clays. Chem Eng J 2011;168:1032-1040.

[35] Do DD. Adsorption Analysis: Equilibria and Kinetics. London: Imperial College Press:1998.

[36] Liu Y, Shen L. A general rate law equation for biosorption. Biochem Eng J. 2008;38:390-394.

[37] Kyzas GZ, Kostoglou M, Lazaridis NK, et al. Environmental friendly technology for the removal of pharmaceutical contaminants from wastewaters using modified chitosan adsorbents. Chem Eng J. 2013;222:248-258.

[38] Gil A, Albeniz S, Korili SA. Valorization of the saline slags generated during secondary aluminium melting processes as adsorbents for the removal of heavy metal ions from aqueous solutions. Chem Eng J. 2014;251:43-50. 
[39] Essandoh M, Kunwar B, Pittman Jr. ChU, et al. Sorptive removal of salicylic acid and ibuprofen from aqueous solutions using pine wood fast pyrolysis biochar. Chem Eng J. $2015 ; 265: 219-227$.

[40] Choy KKH, Porter JF, McKay G. Intraparticle diffusion in single and multicomponent acid dye adsorption from waste water onto carbon. Chem Eng J. 2004;103:133-145.

[41] El Qada EN, Allen SJ, Walker GM. Kinetic modeling of the adsorption of basic dyes onto steam-activated bituminous coal. Ind Eng Chem Res. 2007;46:4764-4771.

[42] Sze MFF, McKay G. An adsorption diffusion model for removal of para-chlorophenol by activated carbon derived from bituminous coal. Environmental Pollution 2010;158:16691674.

[43] Furusawa T, Smith JM. Fluid-particle and intraparticle mass transport rates in slurries. Ind Eng Chem Res. 1973;12:197-203.

[44] Khraisheh M, Al-Degs Y, Allen S, et al. Elucidation of controlling steps of reactive dye adsorption on activated carbon. Ind Eng Chem Res. 2002;41:1651-1657.

[45] Ip AWM, Barford JP, McKay G. Reactive black dye adsorption/desorption onto different adsorbents: Effect of salt, surface chemistry, pore size and surface area. J Colloid Interface Sci. 2009;337:32-38.

[46] Gregg SJ, Sing KSW. Adsorption, Surface Area and Porosity. New York: Academic Press; 1991.

[47] Rouquerol F, Rouquerol J, Sing K. Adsorption by Powders and Porous Solids. San Diego: Academic Press; 1999.

[48] Chu KH. Removal of copper from aqueous solution by chitosan in prawn shell: adsorption equilibrium and kinetics. J Hazard Mater. 2002;90:77-95.

[49] McKay G, Bino MJ, Altamemi A. External mass transfer during the adsorption of various pollutants onto activated carbon. Water Res. 1986;20:435-442. 
[50] Al-Duri B, McKay G. Basic dye adsorption on carbon using a solid-phase diffusion model. Chem Eng J. 1988;38:23-31.

[51] Walker G, Weatherley L. Kinetics of acid dye adsorption of GAC. Water Res. 1999;33:1895-1899.

[52] Yang X-Y, Al-Duri B. Application of branched pore diffusion model in the adsorption of reactive dyes on activated carbon. Chem Eng J. 2001;83:15-23.

[53] Azizian S, Haerifar M, Bashiri H. Adsorption of methyl violet onto granular activated carbon: Equilibrium, kinetics and modeling. Chem Eng J. 2009;146:36-41.

[54] Giles CH, Smith D, Huitson A. A general treatment and classification of the solute adsorption isotherm. J Colloid Interface Sci. 1974;47:755-765.

[55] Keiluweit M, Kleber M. Molecular-leverl interactions in soils and sediments: the role of aromatic $\pi$-systems. Environ Sci Tecnol 2009; 43: 3421-3429.

[56] Mao ZG, Sinnott SB. Separation of organic molecular mixtures in carbon nanotubes and bundles:Molecular dynamics simulations. J Phys Chem B 2001;105:6915-6924.

[57] Liu CH, Li JJ, Zhang HL, et al. Structure dependent interaction between organic dyes and carbon nanotubes. Colloid Surf A 2008;313:9-12. 


\section{Captions}

Table 1. General characteristics of the adsorbates (available from: http://chem.nlm.nih.gov/chemidplus/).

Table 2. Pseudo-first-order parameters for the adsorption of organic molecules by the activated carbon. $\mathrm{T}=298 \mathrm{~K}$ and $\mathrm{pH} 6$.

Table 3. Pseudo-second-order parameters for the adsorption of organic molecules by the activated carbon. $\mathrm{T}=298 \mathrm{~K}$ and $\mathrm{pH} 6$.

Table 4. External mass transfer for the adsorption of organic molecules by the activated carbon. $\mathrm{T}=298 \mathrm{~K}$ and $\mathrm{pH}=6$.

Table 5. Intraparticle rate parameters for the adsorption of organic molecules by the activated carbon. $\mathrm{T}=298 \mathrm{~K}$ and $\mathrm{pH} 6$.

Table 6. Effective diffusion coefficients for the adsorption of organic molecules by the activated carbon. $\mathrm{T}=298 \mathrm{~K}$ and $\mathrm{pH} 6$.

Table 7. Freundlich, Langmuir and Toth parameters for the adsorption of organic molecules by the activated carbon. Equilibrium time $=2 \mathrm{~h}, \mathrm{~T}=298 \mathrm{~K}, \mathrm{pH} 6$.

Figure 1. Kinetic adsorption data for clofibric (CA), gallic (GA) and salicylic (SA) acids on activated carbon considering two adsorption pHs $(2.8$ and 6$) . \mathrm{T}=298 \mathrm{~K}, 15$ $\mathrm{mg} / \mathrm{dm}^{3}$ and $50 \mathrm{mg}$.

Figure 2. Kinetic adsorption data for clofibric, gallic and salicylic acids on the activated carbon considering various acid concentrations and adsorbent amounts. $\mathrm{T}=298$ $\mathrm{K}, \mathrm{pH}$ 6. The lines represent a pseudo-first-order model (-) and a pseudosecond-order model (---).

Figure 3. Kinetic adsorption data for caffeine, diclofenac and ibuprofen on the activated carbon considering various acid concentrations and adsorbent amounts. $\mathrm{T}=298$ $\mathrm{K}, \mathrm{pH}$ 6. The lines represent a pseudo-first-order model (-) and a pseudosecond-order model (---).

Figure 4. Kinetic adsorption data for organic molecules on the activated carbon considering $15 \mathrm{mg} / \mathrm{dm}^{3}$ of acid and $25 \mathrm{mg}$ of adsorbent. $\mathrm{T}=298 \mathrm{~K}, \mathrm{pH}$. The lines represent a pseudo-first-order model (-) and a pseudo-second-order model (---).

Figure 5. Furusawa-Smith model for the adsorption of organic molecules on the activated carbon. $\mathrm{T}=298 \mathrm{~K}$ and $\mathrm{pH} 6$. 
Figure 6. Intraparticle diffusion model for the adsorption of organic molecules on the activated carbon. $\mathrm{T}=298 \mathrm{~K}$ and $\mathrm{pH} 6$.

Figure 7. Experimental (symbols) and model (lines) isotherms for the equilibrium adsorption of organic molecules on the activated carbon. Equilibrium time $=2 \mathrm{~h}, \mathrm{~T}=298 \mathrm{~K}$, pH 6. 
Table 1. General characteristics of the adsorbates (available from: http://chem.nlm.nih.gov/chemidplus/).

\begin{tabular}{|c|c|c|c|c|c|c|}
\hline Characteristic & Clofibric acid & Gallic acid & Salicylic acid & Caffeine & Diclofenac & Ibuprofen \\
\hline $\begin{array}{l}\text { Molecular } \\
\text { structure }\end{array}$ & & $\mathrm{OH}$ & & & & \\
\hline IUPAC name & $\begin{array}{c}\text { 2-(4-Chlorophenoxy)- } \\
\text { 2-methylpropionic } \\
\text { acid }\end{array}$ & $\begin{array}{c}3,4,5- \\
\text { Trihydroxybenzoic } \\
\text { acid }\end{array}$ & $\begin{array}{c}2- \\
\text { Hydroxybenzoic } \\
\text { acid }\end{array}$ & $\begin{array}{c}\text { 1,3,7- } \\
\text { Trimethylpurine- } \\
\text { 2,6-dione }\end{array}$ & $\begin{array}{c}\text { 2-(2,6- } \\
\text { Dichloranilino) } \\
\text { phenylacetic } \\
\text { acid }\end{array}$ & $\begin{array}{c}(R S)-2- \\
\text { (4-(2-Methylpropyl)phenyl) } \\
\text { propanoic acid }\end{array}$ \\
\hline $\begin{array}{l}\text { Chemical } \\
\text { formula }\end{array}$ & $\mathrm{C}_{10} \mathrm{H}_{11} \mathrm{ClO}_{3}$ & $\mathrm{C}_{7} \mathrm{H}_{6} \mathrm{O}_{5}$ & $\mathrm{C}_{7} \mathrm{H}_{6} \mathrm{O}_{3}$ & $\mathrm{C}_{8} \mathrm{H}_{10} \mathrm{~N}_{4} \mathrm{O}_{2}$ & $\mathrm{C}_{14} \mathrm{H}_{11} \mathrm{Cl}_{2} \mathrm{NO}_{2}$ & $\mathrm{C}_{13} \mathrm{H}_{18} \mathrm{O}_{2}$ \\
\hline $\begin{array}{c}\text { Molecular } \\
\text { weight }\end{array}$ & 214.65 & 170.12 & 138.12 & 194.19 & 296.15 & 206.28 \\
\hline $\mathrm{pK}_{\mathrm{a}}{ }^{1}$ & 2.8 & 3.13 & 2.97 & 10.4 & 4.15 & 4.9 \\
\hline$\lambda_{\max }(\mathrm{nm})^{2}$ & 227 & 268 & 230 & 273 & 276 & 222 \\
\hline
\end{tabular}

${ }^{1} \mathrm{~K}_{\mathrm{a}}$ : dissociation constant at $20^{\circ} \mathrm{C}$

${ }^{2} \lambda_{\max }$ : maximum absorption wavelength, determined experimentally 
Table 2. Pseudo-first-order parameters for the adsorption of organic molecules by the activated carbon. $\mathrm{T}=298 \mathrm{~K}$ and $\mathrm{pH} 6$.

\begin{tabular}{|c|c|c|c|c|c|c|}
\hline & Clofibric acid & Gallic acid & Salicylic acid & Caffeine & Diclofenac & Ibuprofen \\
\hline \multicolumn{7}{|c|}{$5 \mathrm{mg} / \mathrm{dm}^{3}-50 \mathrm{mg}$} \\
\hline$k_{1}(1 / \mathrm{min})$ & 0.34 & 0.093 & 0.083 & 0.11 & 0.14 & 0.09 \\
\hline$\chi^{2}$ & 0.033 & 0.10 & 0.11 & 0.0025 & 0.0017 & 0.0068 \\
\hline $\mathrm{R}$ & 0.96 & 0.94 & 0.96 & 0.96 & 0.98 & 0.91 \\
\hline \multicolumn{7}{|c|}{$10 \mathrm{mg} / \mathrm{dm}^{3}-50 \mathrm{mg}$} \\
\hline$k_{1}(1 / \mathrm{min})$ & 0.63 & 0.060 & 0.086 & 0.11 & 0.11 & 0.18 \\
\hline$\chi^{2}$ & 0.083 & 0.15 & 0.12 & 0.04 & 0.04 & 0.067 \\
\hline $\mathrm{R}$ & 0.97 & 0.98 & 0.992 & 0.98 & 0.98 & 0.96 \\
\hline \multicolumn{7}{|c|}{$15 \mathrm{mg} / \mathrm{dm}^{3}-50 \mathrm{mg}$} \\
\hline$k_{1}(1 / \mathrm{min})$ & 0.18 & 0.12 & 0.097 & 0.12 & 0.095 & 0.061 \\
\hline$\chi^{2}$ & 2.8 & 0.34 & 1.5 & 0.14 & 0.23 & 0.24 \\
\hline$\tilde{\mathrm{R}}$ & 0.82 & 0.98 & 0.93 & 0.993 & 0.98 & 0.990 \\
\hline \multicolumn{7}{|c|}{$15 \mathrm{mg} / \mathrm{dm}^{3}-25 \mathrm{mg}$} \\
\hline$k_{1}(1 / \mathrm{min})$ & 0.19 & 0.032 & 0.25 & 0.041 & 0.053 & 0.027 \\
\hline$\chi^{2}$ & 4.0 & 0.36 & 4.0 & 0.97 & 0.32 & 1.27 \\
\hline $\mathrm{R}$ & 0.84 & 0.997 & 0.93 & 0.98 & 0.994 & 0.98 \\
\hline \multicolumn{7}{|c|}{$15 \mathrm{mg} / \mathrm{dm}^{3}-100 \mathrm{mg}$} \\
\hline$k_{1}(1 / \mathrm{min})$ & 0.26 & 0.14 & 0.26 & 0.14 & 0.20 & 0.18 \\
\hline$\chi^{2}$ & 0.51 & 0.048 & 0.16 & 0.025 & 0.083 & 0.079 \\
\hline $\mathrm{R}$ & 0.87 & 0.991 & 0.97 & 0.995 & 0.98 & 0.990 \\
\hline
\end{tabular}


Table 3. Pseudo-second-order parameters for the adsorption of organic molecules by the activated carbon. T = $298 \mathrm{~K}$ and $\mathrm{pH} 6$.

\begin{tabular}{|c|c|c|c|c|c|c|}
\hline & Clofibric acid & Gallic acid & Salicylic acid & Caffeine & Diclofenac & Ibuprofen \\
\hline \multicolumn{7}{|l|}{$5 \mathrm{mg} / \mathrm{dm}^{3}-50 \mathrm{mg}$} \\
\hline$k_{2}(\mathrm{~g} / \mathrm{mg} \cdot \min )$ & 1.2 & 0.21 & 0.13 & 0.93 & 1.03 & 0.69 \\
\hline$\chi^{2}$ & 0.024 & 0.12 & 0.13 & 0.0020 & 0.0027 & 0.005 \\
\hline $\mathrm{R}$ & 0.97 & 0.94 & 0.95 & 0.980 & 0.97 & 0.96 \\
\hline \multicolumn{7}{|c|}{$10 \mathrm{mg} / \mathrm{dm}^{3}-50 \mathrm{mg}$} \\
\hline$k_{2}(\mathrm{~g} / \mathrm{mg} \cdot \min )$ & 1.3 & 0.047 & 0.062 & 0.18 & 0.17 & 0.36 \\
\hline$\chi^{2}$ & 0.023 & 0.35 & 0.22 & 0.046 & 0.025 & 0.031 \\
\hline $\mathrm{R}$ & 0.992 & 0.97 & 0.98 & 0.98 & 0.993 & 0.98 \\
\hline \multicolumn{7}{|c|}{$15 \mathrm{mg} / \mathrm{dm}^{3}-50 \mathrm{mg}$} \\
\hline$k_{2}(\mathrm{~g} / \mathrm{mg} \cdot \min )$ & 0.11 & 0.071 & 0.047 & 0.070 & 0.048 & 0.029 \\
\hline$\chi^{2}$ & 1.3 & 0.63 & 0.59 & 0.61 & 0.28 & 0.59 \\
\hline $\mathrm{R}$ & 0.92 & 0.97 & 0.97 & 0.98 & 0.991 & 0.98 \\
\hline \multicolumn{7}{|c|}{$15 \mathrm{mg} / \mathrm{dm}^{3}-25 \mathrm{mg}$} \\
\hline$k_{2}(\mathrm{~g} / \mathrm{mg} \cdot \min )$ & 0.10 & 0.0092 & 0.10 & 0.011 & 0.013 & 0.0077 \\
\hline$\chi^{2}$ & 1.8 & 2.7 & 2.3 & 2.32 & 2.14 & 3.61 \\
\hline $\mathrm{R}$ & 0.93 & 0.98 & 0.96 & 0.98 & 0.98 & 0.98 \\
\hline \multicolumn{7}{|c|}{$15 \mathrm{mg} / \mathrm{dm}^{3}-100 \mathrm{mg}$} \\
\hline$k_{2}(\mathrm{~g} / \mathrm{mg} \cdot \min )$ & 0.37 & 0.17 & 0.37 & 0.15 & 0.24 & 0.21 \\
\hline$\chi^{2}$ & 0.18 & 0.039 & 0.073 & 0.050 & 0.063 & 0.20 \\
\hline $\mathrm{R}$ & 0.95 & 0.993 & 0.98 & 0.993 & 0.98 & 0.97 \\
\hline
\end{tabular}


Table 4. External mass transfer for the adsorption of organic molecules by the activated carbon. $\mathrm{T}=298 \mathrm{~K}$ and $\mathrm{pH}=6$.

\begin{tabular}{|c|c|c|c|}
\hline & Caffeine & Diclofenac & Ibuprofen \\
\hline \multicolumn{4}{|c|}{$5 \mathrm{mg} / \mathrm{dm}^{3}-50 \mathrm{mg}$} \\
\hline$k_{F S}(\mathrm{~cm} / \mathrm{s})$ & $2.1710^{-7}$ & $2.3410^{-7}$ & $29.510^{-7}$ \\
\hline$\chi^{2}$ & 0.20 & 0.30 & 0.48 \\
\hline $\mathrm{R}$ & 0.91 & 0.86 & 0.76 \\
\hline \multicolumn{4}{|c|}{$10 \mathrm{mg} / \mathrm{dm}^{3}-50 \mathrm{mg}$} \\
\hline$k_{F S}(\mathrm{~cm} / \mathrm{s})$ & $2.1310^{-7}$ & $1.8710^{-7}$ & $12.010^{-7}$ \\
\hline$\chi^{2}$ & 0.057 & 0.038 & 0.16 \\
\hline R & 0.98 & 0.98 & 0.92 \\
\hline \multicolumn{4}{|c|}{$15 \mathrm{mg} / \mathrm{dm}^{3}-50 \mathrm{mg}$} \\
\hline$k_{F S}(\mathrm{~cm} / \mathrm{s})$ & $1.5110^{-7}$ & $1.6210^{-7}$ & $1.6310^{-7}$ \\
\hline$\chi^{2}$ & 0.035 & 0.038 & 0.035 \\
\hline $\mathrm{R}$ & 0.98 & 0.98 & 0.991 \\
\hline \multicolumn{4}{|c|}{$15 \mathrm{mg} / \mathrm{dm}^{3}-25 \mathrm{mg}$} \\
\hline$k_{F S}(\mathrm{~cm} / \mathrm{s})$ & $1.4810^{-7}$ & $1.3410^{-7}$ & $0.9310^{-7}$ \\
\hline$\chi^{2}$ & 0.034 & 0.0085 & 0.048 \\
\hline$\tilde{R}$ & 0.991 & 0.997 & 0.98 \\
\hline \multicolumn{4}{|c|}{$15 \mathrm{mg} / \mathrm{dm}^{3}-100 \mathrm{mg}$} \\
\hline$k_{F S}(\mathrm{~cm} / \mathrm{s})$ & $2.1310^{-7}$ & $1.9710^{-7}$ & $8.210^{-7}$ \\
\hline$\chi^{2}$ & 0.012 & 0.046 & 0.046 \\
\hline $\mathrm{R}$ & 0.996 & 0.98 & 0.98 \\
\hline
\end{tabular}


Table 5. Intraparticle rate parameters for the adsorption of organic molecules by the activated carbon. $\mathrm{T}=298 \mathrm{~K}$ and $\mathrm{pH} 6$.

\begin{tabular}{|c|c|c|c|c|c|c|}
\hline & Clofibric acid & Gallic acid & Salicylic acid & Caffeine & Diclofenac & Ibuprofen \\
\hline \multicolumn{7}{|l|}{$5 \mathrm{mg} / \mathrm{dm}^{3}-50 \mathrm{mg}$} \\
\hline$k_{3}^{\prime}\left(\mathrm{mg} / \mathrm{g} \cdot \min ^{0.5}\right)$ & 0.20 & 0.068 & 0.21 & 0.027 & 0.059 & 0.020 \\
\hline $\mathrm{R}$ & 0.98 & 0.997 & 0.97 & 0.94 & 0.97 & 0.95 \\
\hline$k^{\prime \prime}{ }_{3}\left(\mathrm{mg} / \mathrm{g} \cdot \min ^{0.5}\right)$ & 0.0061 & 0.052 & 0.037 & 0.0026 & 0.0049 & 0.0020 \\
\hline $\mathrm{R}$ & 0.96 & 0.98 & 0.98 & 0.69 & 0.75 & 0.5 \\
\hline \multicolumn{7}{|l|}{$10 \mathrm{mg} / \mathrm{dm}^{3}-50 \mathrm{mg}$} \\
\hline$k_{3}^{\prime}\left(\mathrm{mg} / \mathrm{g} \cdot \min ^{0.5}\right)$ & 0.23 & 0.18 & 0.58 & 0.17 & 0.22 & 0.19 \\
\hline $\mathrm{R}$ & 0.992 & 0.96 & 0.97 & 0.97 & 0.97 & 0.94 \\
\hline$k{ }_{3}\left(\mathrm{mg} / \mathrm{g} \cdot \mathrm{min}^{0.5}\right)$ & 0.0023 & 0.076 & 0.044 & 0.019 & 0.035 & 0 \\
\hline $\mathrm{R}$ & 0.96 & 0.93 & 0.94 & 0.97 & 0.98 & 0.48 \\
\hline \multicolumn{7}{|l|}{$15 \mathrm{mg} / \mathrm{dm}^{3}-50 \mathrm{mg}$} \\
\hline$k_{3}^{\prime}\left(\mathrm{mg} / \mathrm{g} \cdot \min ^{0.5}\right)$ & 0.14 & 0.23 & 0.43 & 0.70 & 0.58 & 0.46 \\
\hline $\mathrm{R}$ & 0.96 & 0.95 & 0.94 & 0.98 & 0.97 & 0.95 \\
\hline$k{ }_{3}\left(\mathrm{mg} / \mathrm{g} \cdot \mathrm{min}^{0.5}\right)$ & 0.13 & 0.032 & 0.21 & 0.0070 & 0.087 & 0.068 \\
\hline $\mathrm{R}$ & 0.85 & 0.98 & 0.97 & 1 & 0.97 & 0.85 \\
\hline \multicolumn{7}{|l|}{$15 \mathrm{mg} / \mathrm{dm}^{3}-25 \mathrm{mg}$} \\
\hline$k_{3}^{\prime}\left(\mathrm{mg} / \mathrm{g} \cdot \min ^{0.5}\right)$ & 0.15 & 0.39 & 0.94 & 0.81 & 0.81 & 0.71 \\
\hline $\mathrm{R}$ & 0.98 & 0.81 & 0.95 & 0.96 & 0.97 & 0.97 \\
\hline$k{ }^{\prime}{ }_{3}\left(\mathrm{mg} / \mathrm{g} \cdot \min ^{0.5}\right)$ & 0.10 & 0.21 & 0.13 & 0.55 & 0.085 & 0.12 \\
\hline $\mathrm{R}$ & 0.92 & 0.991 & 0.92 & 0.998 & 0.97 & 0.97 \\
\hline \multicolumn{7}{|l|}{$15 \mathrm{mg} / \mathrm{dm}^{3}-100 \mathrm{mg}$} \\
\hline$k_{3}^{\prime}\left(\mathrm{mg} / \mathrm{g} \cdot \min ^{0.5}\right)$ & 0.12 & 0.41 & 0.31 & 0.38 & 0.38 & 0.44 \\
\hline $\mathrm{R}$ & 0.90 & 0.92 & 0.93 & 0.996 & 0.991 & 0.97 \\
\hline$k^{\prime}{ }_{3}\left(\mathrm{mg} / \mathrm{g} \cdot \min ^{0.5}\right)$ & 0.041 & 0.013 & 0.023 & 0.0081 & 0.00009 & -- \\
\hline $\mathrm{R}$ & 0.85 & 0.94 & 0.97 & 0.83 & 0.03 & -- \\
\hline
\end{tabular}


Table 6. Effective diffusion coefficients for the adsorption of organic molecules by the activated carbon. $\mathrm{T}=298 \mathrm{~K}$ and $\mathrm{pH} 6$.

\begin{tabular}{|c|c|c|c|}
\hline & Caffeine & Diclofenac & Ibuprofen \\
\hline \multicolumn{4}{|c|}{$5 \mathrm{mg} / \mathrm{dm}^{3}-50 \mathrm{mg}$} \\
\hline$D / r^{2}(1 / s)$ & $2.2410^{-5}$ & $2.4210^{-5}$ & $1.7610^{-5}$ \\
\hline$\chi^{2}$ & 0.12 & 0.19 & 0.20 \\
\hline$\stackrel{n}{\mathrm{R}}$ & 0.97 & 0.95 & 0.95 \\
\hline \multicolumn{4}{|c|}{$10 \mathrm{mg} / \mathrm{dm}^{3}-50 \mathrm{mg}$} \\
\hline$D / r^{2}(1 / \mathrm{s})$ & $3.0310^{-5}$ & $2.9510^{-5}$ & $5.4410^{-5}$ \\
\hline$\chi^{2}$ & 0.16 & 0.11 & 0.075 \\
\hline $\mathrm{R}$ & 0.97 & 0.98 & 0.98 \\
\hline \multicolumn{4}{|c|}{$15 \mathrm{mg} / \mathrm{dm}^{3}-50 \mathrm{mg}$} \\
\hline$D / r^{2}(1 / s)$ & $3.6010^{-5}$ & $2.5610^{-5}$ & $1.8910^{-5}$ \\
\hline$\chi^{2}$ & 0.27 & 0.17 & 0.30 \\
\hline $\mathrm{R}$ & 0.95 & 0.96 & 0.94 \\
\hline \multicolumn{4}{|c|}{$15 \mathrm{mg} / \mathrm{dm}^{3}-25 \mathrm{mg}$} \\
\hline$D / r^{2}(1 / s)$ & $1.4010^{-5}$ & $1.2910^{-5}$ & $1.0510^{-5}$ \\
\hline$\chi^{2}$ & 0.36 & 0.41 & 0.43 \\
\hline $\mathrm{n}$ & 0.93 & 0.89 & 0.91 \\
\hline \multicolumn{4}{|c|}{$15 \mathrm{mg} / \mathrm{dm}^{3}-100 \mathrm{mg}$} \\
\hline$D / r^{2}(1 / s)$ & $4.4910^{-5}$ & $7.1510^{-5}$ & $5.4710^{-5}$ \\
\hline$\chi^{2}$ & 0.13 & 0.11 & 0.24 \\
\hline $\mathrm{R}$ & 0.97 & 0.97 & 0.94 \\
\hline
\end{tabular}


Table 7. Freundlich, Langmuir and Toth parameters for the adsorption of organic molecules by the activated carbon. Equilibrium time $=2 \mathrm{~h}, \mathrm{~T}=$ 298 K, pH 6.

\begin{tabular}{lrrrr}
\hline & Salicylic acid & Caffeine & Diclofenac & Ibuprofen \\
\hline Freundlich & 7.3 & 12 & 5.0 & \\
$q_{F}$ & 3.7 & 2.4 & 2.4 & 4.5 \\
$m_{F}$ & 46 & 252 & 37 & 74 \\
$\chi^{2}$ & 0.97 & 0.98 & 0.993 & 0.97 \\
$\mathrm{R}$ & & & & \\
Langmuir & 33 & 88 & 64 & 34 \\
$q_{L}(\mathrm{mg} / \mathrm{g})$ & 0.073 & 0.094 & 0.014 & 0.26 \\
$k_{L}(\mathrm{dm} / \mathrm{mg})$ & 152 & 58 & 115 & 143 \\
$\chi^{2}$ & 0.92 & 0.996 & 0.98 & 0.95 \\
$\mathrm{R}$ & & & & 247 \\
Toth & 422 & 112 & 2557 & 3895 \\
$q_{T}(\mathrm{mg} / \mathrm{g})$ & 1043 & 0.16 & 0.61 & 0.11 \\
$k_{T}(\mathrm{dm} / \mathrm{mg})$ & 0.10 & 0.57 & 0.11 & 70 \\
$m_{T}$ & 55 & 17 & 46 & 0.97 \\
$\chi^{2}$ & 0.97 & 0.998 & 0.991 & \\
$\mathrm{R}$ & & & & \\
\hline
\end{tabular}



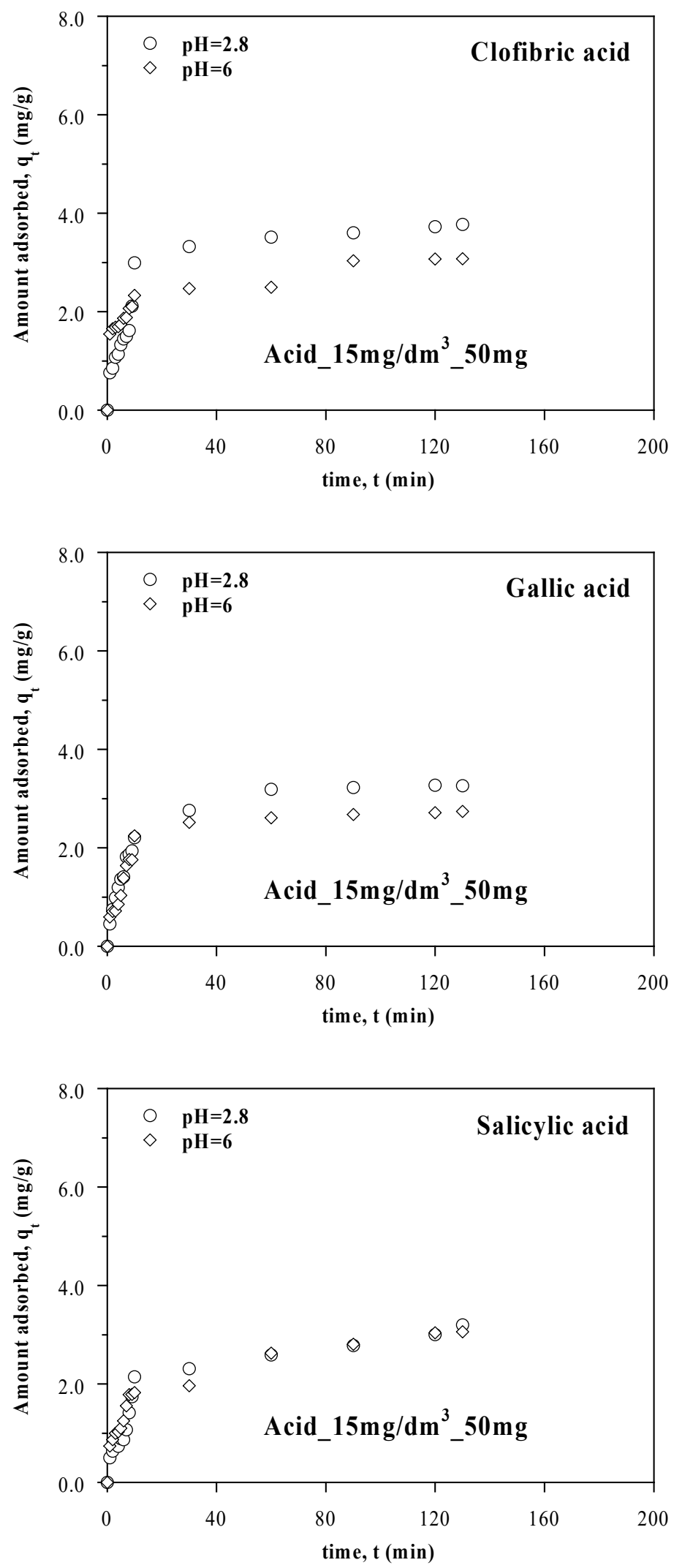

Figure 1. Kinetic adsorption data for clofibric (CA), gallic (GA) and salicylic (SA) acids on activated carbon considering two adsorption pHs $(2.8$ and 6$) . \mathrm{T}=298 \mathrm{~K}, 15 \mathrm{mg} / \mathrm{dm}^{3}$ and 50 mg. 

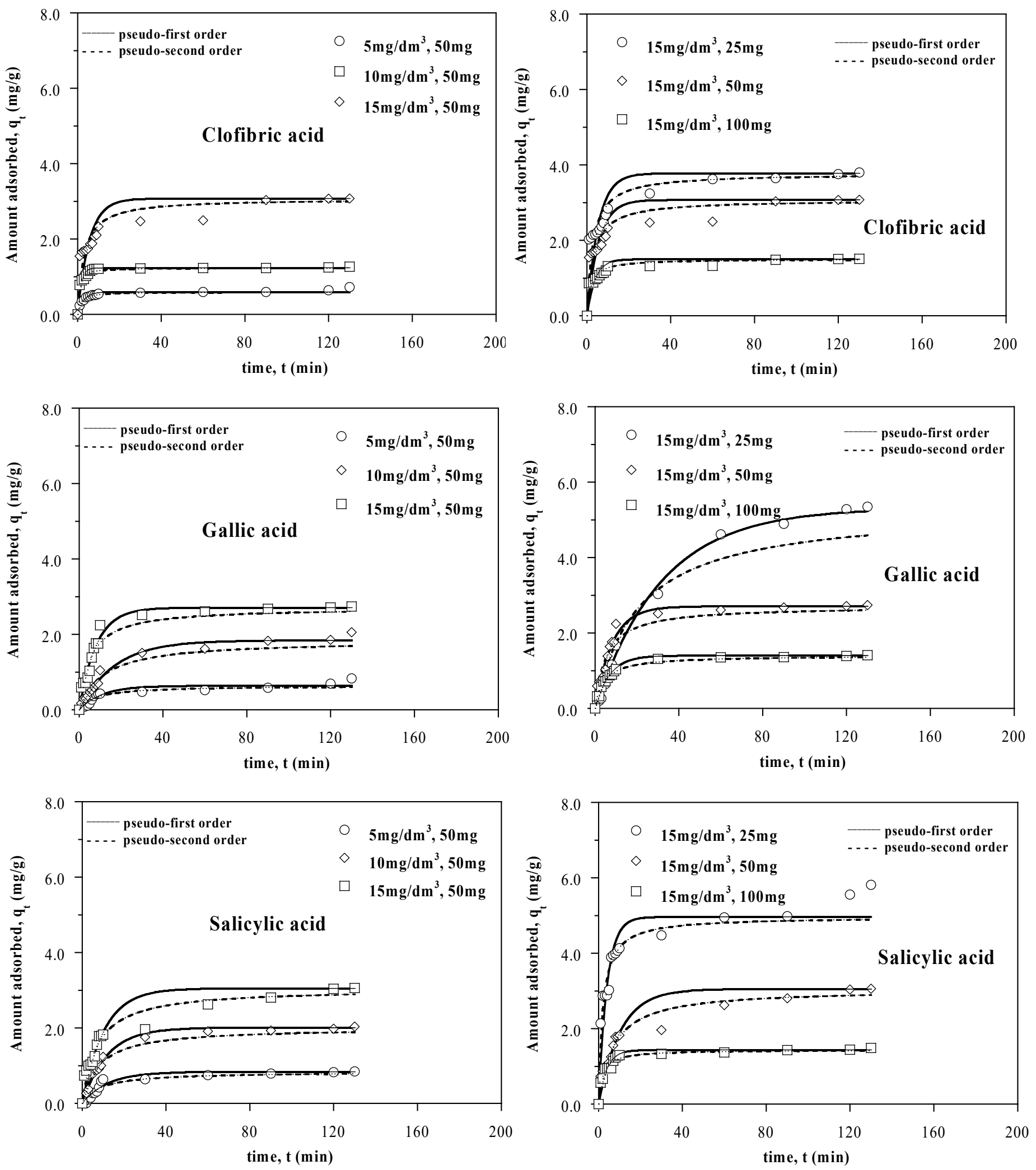

Figure 2. Kinetic adsorption data for clofibric, gallic and salicylic acids on the activated carbon considering various acid concentrations and adsorbent amounts. $\mathrm{T}=298 \mathrm{~K}, \mathrm{pH} 6$. The lines represent a pseudo-first-order model (-) and a pseudo-second-order model (---). 

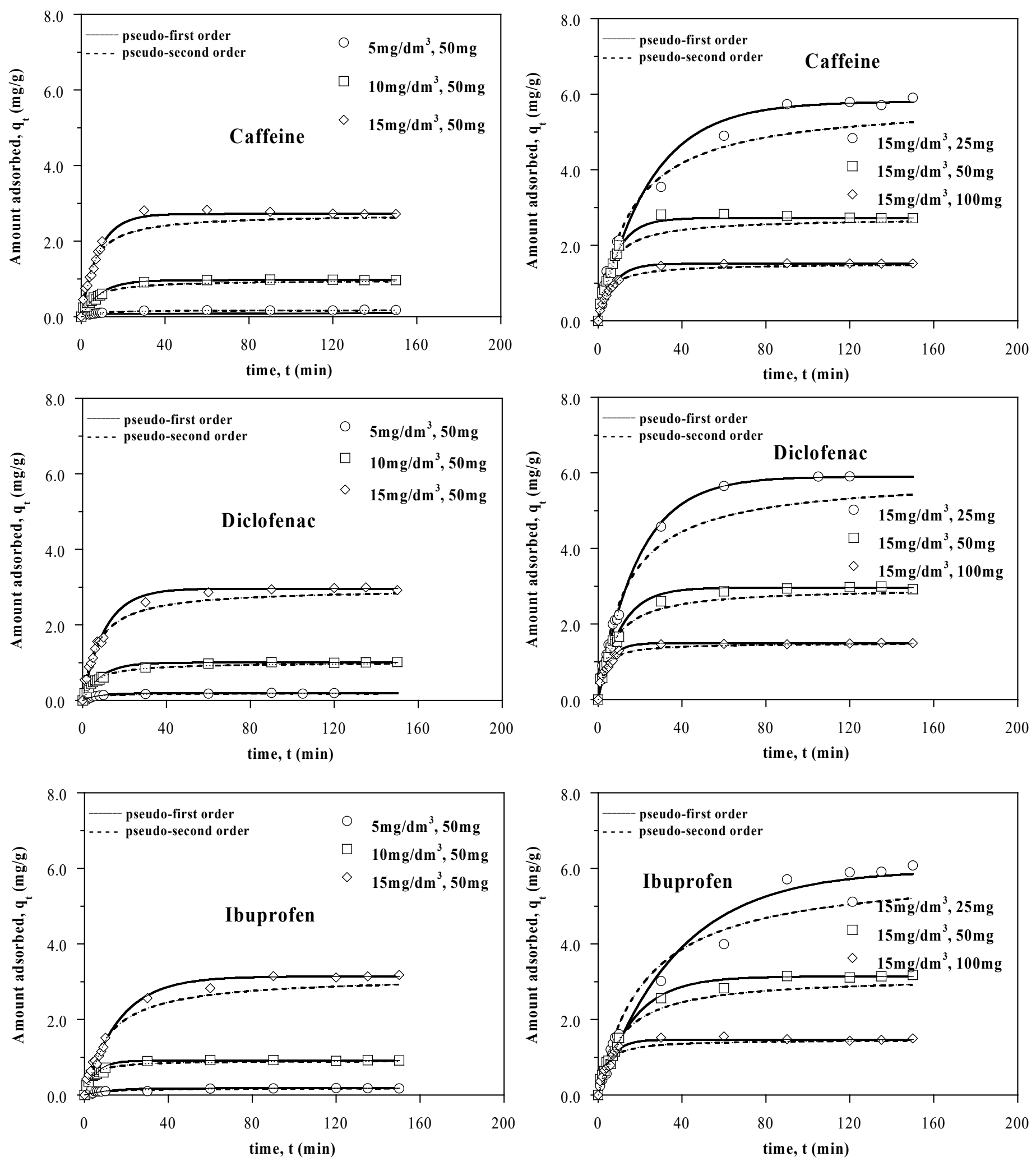

Figure 3. Kinetic adsorption data for caffeine, diclofenac and ibuprofen on the activated carbon considering various acid concentrations and adsorbent amounts. $\mathrm{T}=298 \mathrm{~K}, \mathrm{pH}$ 6. The lines represent a pseudo-first-order model (-) and a pseudo-second-order model (---). 

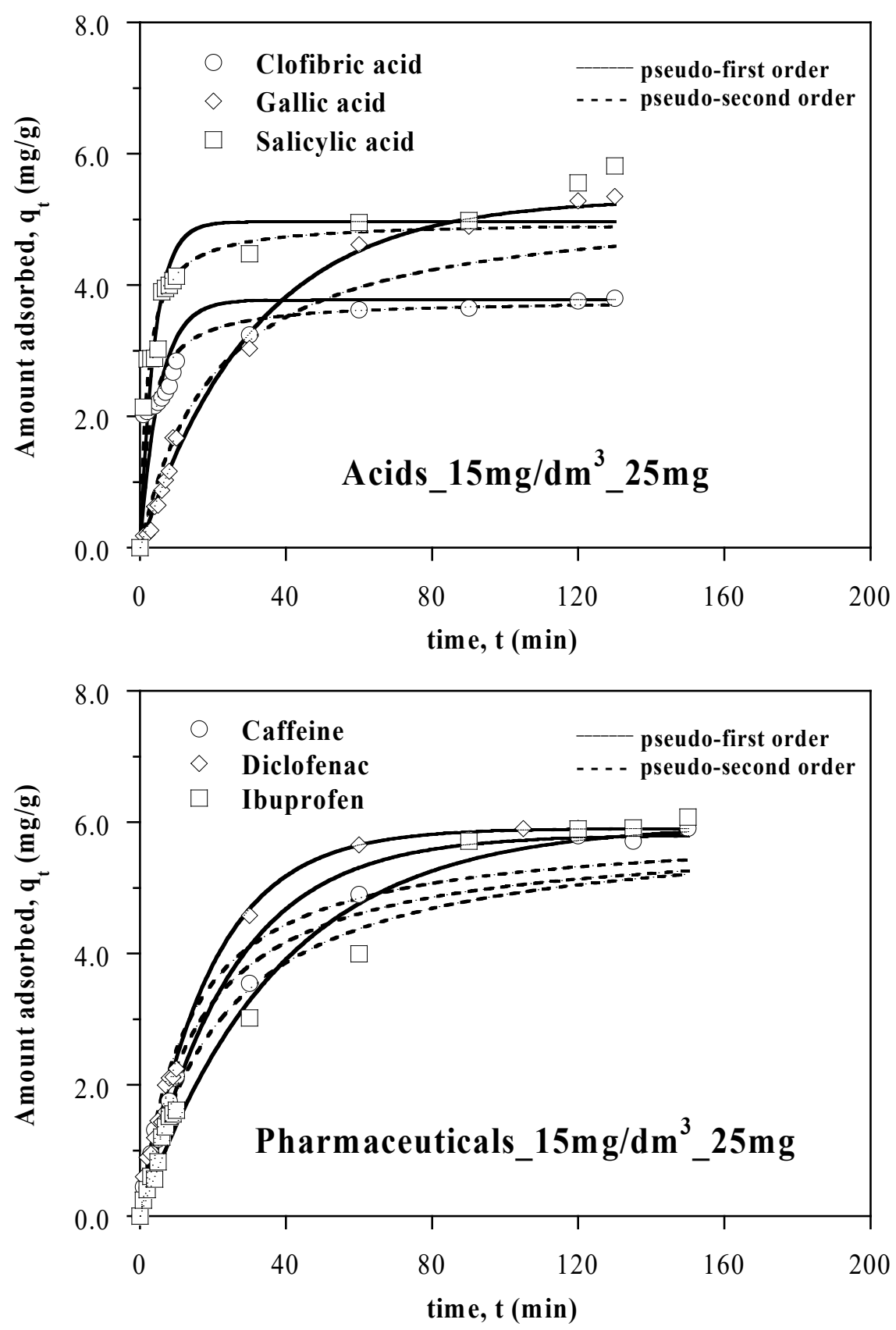

Figure 4. Kinetic adsorption data for organic molecules on the activated carbon considering $15 \mathrm{mg} / \mathrm{dm}^{3}$ of acid and $25 \mathrm{mg}$ of adsorbent. $\mathrm{T}=298 \mathrm{~K}, \mathrm{pH} 6$. The lines represent a pseudofirst-order model (-) and a pseudo-second-order model (---). 

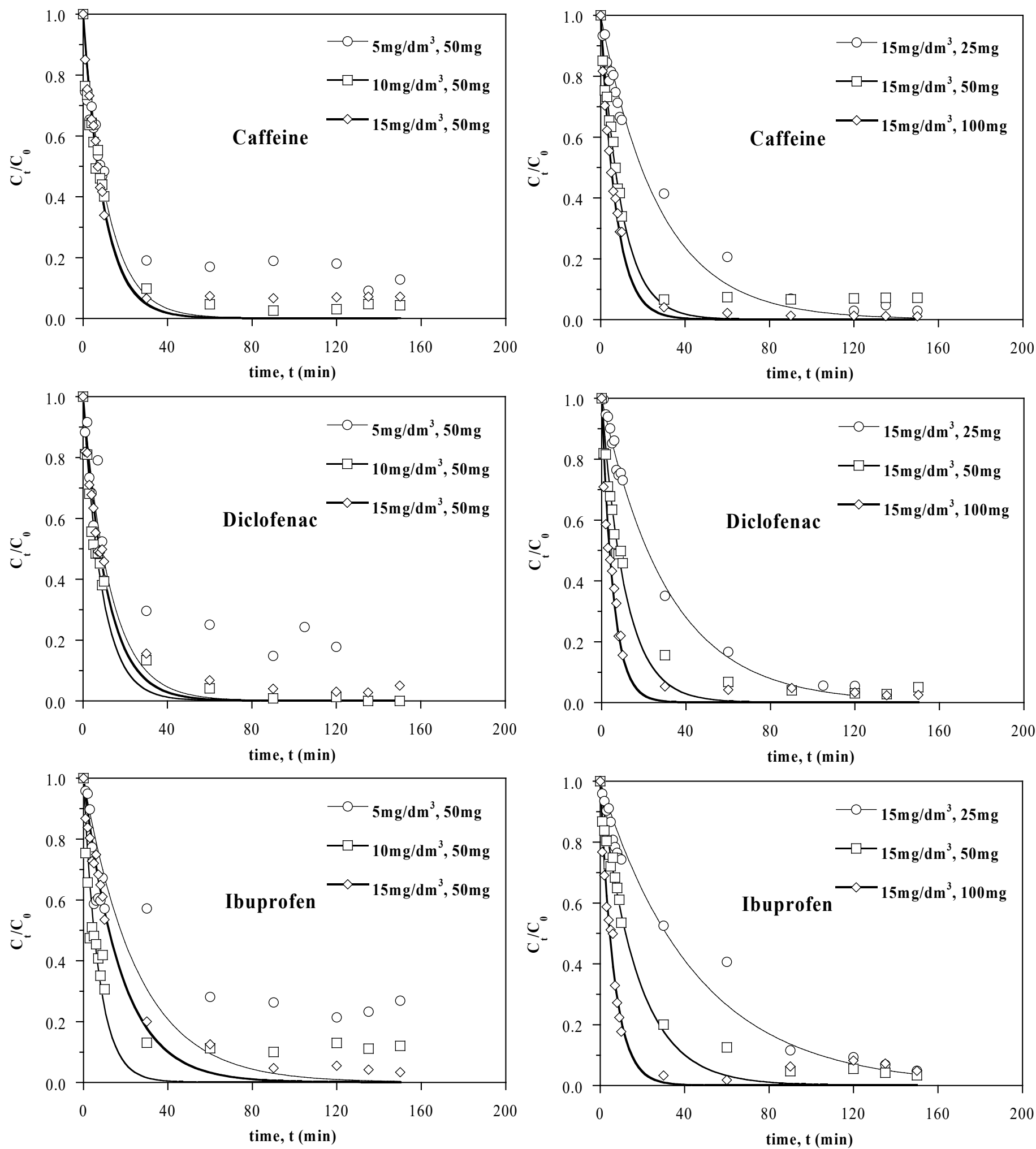

Figure 5. Furusawa-Smith model for the adsorption of organic molecules on the activated carbon. $\mathrm{T}=298 \mathrm{~K}$ and $\mathrm{pH} 6$. 

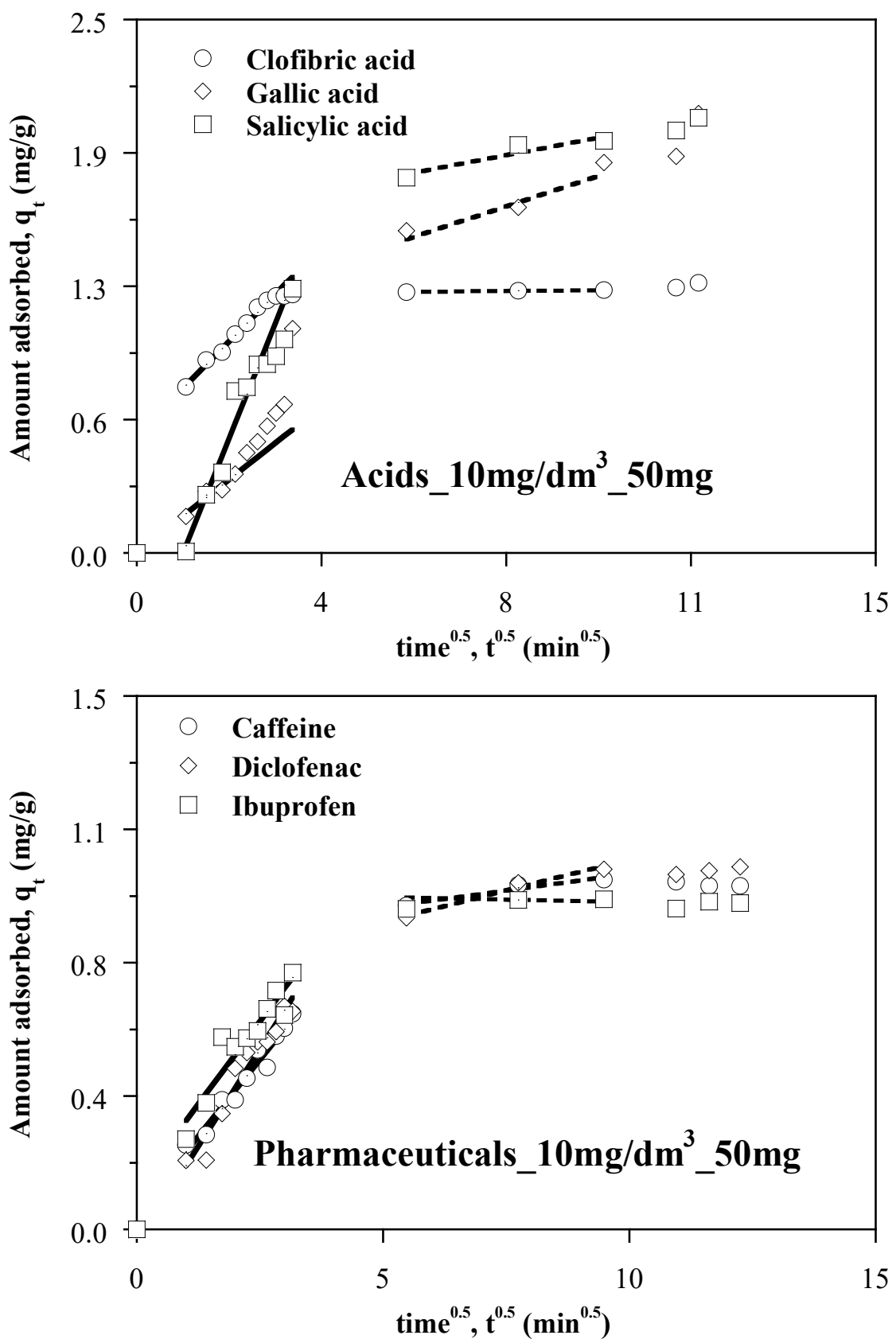

Figure 6. Intraparticle diffusion model for the adsorption of organic molecules on the activated carbon. $\mathrm{T}=298 \mathrm{~K}$ and $\mathrm{pH} 6$. 


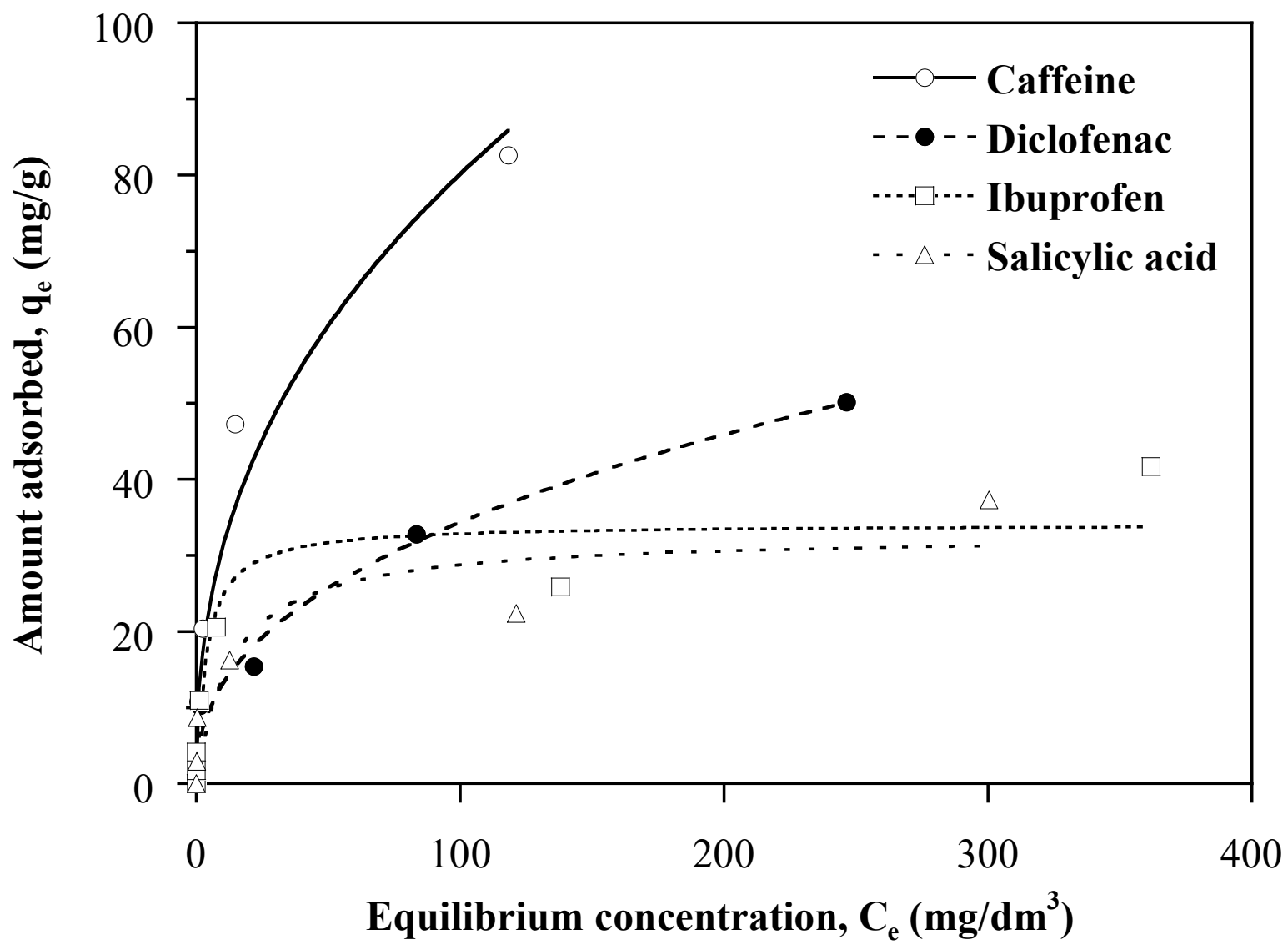

Figure 7. Experimental (symbols) and model (lines) isotherms for the equilibrium adsorption of organic molecules on the activated carbon. Equilibrium time $=2 \mathrm{~h}, \mathrm{~T}=298 \mathrm{~K}, \mathrm{pH} 6$. 